Volume 1 Nomor 2, Agustus 2016, halaman 123-134

\title{
PENGEMBANGAN BAHAN AJAR STATISTIKA BERBASIS INFORMATION AND COMMUNICATION TECHNOLOGY (ICT)
}

\author{
Hamidah Suryani Lukman ${ }^{1}$ dan Astri Sutisnawati ${ }^{2}$ \\ ${ }^{1}$ Universitas Muhammadiyah Sukabumi, hamni_alkhawarizmi@yahoo.co.id \\ ${ }^{2}$ Universitas Muhammadiyah Sukabumi, astrisutisna@gmail.com
}

\begin{abstract}
ABSTRAK
Makalah ini merupakan hasil penelitian pengembangan mengenai bahan ajar statistika berbasis ICT. Metode yang digunakan adalah Research and Development tahap awal yang diaplikasikan dalam 2 tahap penelitian. Tahap pertama melakukan analisis bahan ajar yang dikembangkan melalui studi literatur; mengembangkan produk awal; validasi tim ahli; dan melakukan revisi 1 . Tahap kedua melakukan uji terbatas terhadap 13 orang mahasiswa peserta mata kuliah Statistika pada Program Studi Pendidikan Matematika Universitas Muhammadiyah Sukabumi, yang dipilih secara acak dan melakukan revisi 2. Metode yang digunakan pada tahap kedua adalah eksperimen single one shot case study. Instrumen yang digunakan dalam penelitian ini berupa lembar validasi, lembar efektivitas kinerja bahan ajar, dan tes kemampuan pemahaman konsep matematis. Data ini dianalisis menggunakan analisis deskriptif dan uji Wilcoxon Signed Ranks Test pada taraf $\alpha=$ $5 \%$. Hasil penelitian menunjukkan rata-rata skor validasi bahan ajar adalah 4,50 dari total skor 5. Hal ini menunjukkan bahwa lebih dari $80 \%$ bahan ajar berbasis ICT yang dikembangkan sudah layak digunakan (valid) dan tergolong kategori sangat baik. Berdasarkan hasil uji coba, pencapaian kemampuan pemahaman konsep mahasiswa sesudah menggunakan bahan ajar statistika berbasis ICT lebih baik secara signifikan dari pada sebelum menggunakan bahan ajar berbasis ICT. Selain itu, penilaian keseluruhan efektivitas kinerja bahan ajar berbasis ICT mencapai $62.98 \%$. Hal ini lebih
\end{abstract}

\section{ABSTRACT}

This paper is the research and development result of Statistics teaching materials based on ICT. The method used is the early stage of research and development that applied on the second phase of the study. The first stage is analysis the teaching materials through the study of literature; developing initial products; experts team validation; and first revised. The second phase is limited test to 13 students randomly selected that participated in the course Statistics on Mathematics Education Universitas Muhammadiyah Sukabumi, and do the second revised. The method used in the second stage is a single experiment one shot case study. The instrument used in this study are validation sheet, teaching materials performance and effectiveness sheet, and conceptual understanding test. These data were analyzed using descriptive analysis and Wilcoxon Signed Ranks Test on the level of $\alpha$ $=5 \%$. The results showed that average score of teaching materials validation is 4.50 out of 5. This result indicates that more than $80 \%$ of ICT based teaching materials developed is feasible to use (valid) and classified as very well category. Based on trial results, conceptual understanding ability of students after using ICT based teaching materials significantly better than before using ICT based teaching materials. In addition, an overall assessment of performance effectiveness of ICT based teaching material reached $62.98 \%$ higher than the learning without ICT based teaching materials, which only reached $60.58 \%$. These results indicate that using ICT based teaching materials in 
tinggi dibandingkan dengan penilaian efektivitas kinerja pembelajaran tanpa bahan ajar berbasis ICT yang hanya mencapai $60.58 \%$. Hasil tersebut menunjukkan bahwa penggunaan bahan ajar statistika berbasis ICT sudah memenuhi kriteria valid, praktis, dan efektif digunakan dalam pembelajaran, khususnya sebagai upaya menumbuhkembangkan kemampuan pemahaman konsep matematis mahasiswa.

Kata Kunci: Bahan Ajar, Pemahaman Konsep Matematis, ICT. learning has the valid, practical, and effective criteria, particularly in an effort to develop the students' conceptual understanding ability.

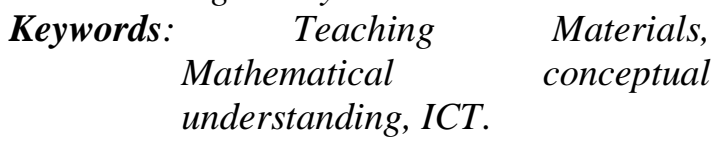

\section{How to Cite : Lukman, H. S., \& Sutisnawati, A. (2016). Pengembangan Bahan Ajar Statistika Berbasis Information and Communication Technology (ICT). Mathline: Jurnal Matematika dan Pendidikan Matematika, Vol.1, No.2, 123-134.}

\section{PENDAHULUAN}

Jenjang kualifikasi bagi sarjana di dalam Kerangka Kualifikasi Nasional Indonesia (KKNI) berada pada tingkat kualifikasi level 6. Deskripsi jenjang kualifikasi ini, khususnya bagi sarjana pendidikan matematika (level 6 pada paragraf pertama) salah satunya adalah mampu memanfaatkan IPTEKS dalam bidang keahliannya dan mampu beradaptasi terhadap situasi yang dihadapi dalam penyelesaian masalah (Belmawa \& ALPTKI, 2013). Sehingga berdasarkan jenjang kualifikasi tersebut, salah satu kompetensi utama yang harus dikuasai mahasiswa sebagai capaian pembelajaran (learning outcome) diantaranya: 1) mampu mengaplikasikan konsep dan prinsip didaktik-pedagogis matematika untuk melakukan evaluasi dengan memanfaatkan IPTEKS yang berorierentasi pada kecakapan hidup (life skills); 2) mampu merancang dan melaksanakan penelitian sederhana serta melaporkan dan atau mempublikasikan hasilnya, sehingga dapat digunakan sebagai alternatif penyelesaian masalah di bidang pendidikan matematika.

Sejalan dengan aturan KKNI, Peraturan Menteri Pendidikan Nasional Nomor 2 tahun 2010 tentang Rencana Strategis Kementerian Pendidikan Nasional 2010-2014 mengemukakan bahwa kebutuhan akan penguasaan dan penerapan IPTEK dalam rangka menghadapi tuntutan global berdampak pada semakin meningkatnya peranan information and communication technology (ICT) dalam berbagai aspek kehidupan, termasuk dalam bidang pendidikan, meningkatnya kebutuhan untuk berbagi informasi dan pengetahuan 
dengan memanfaatkan ICT, serta perkembangan internet yang menghilangkan batas wilayah dan waktu untuk melakukan komunikasi dan akses terhadap informasi (Kemdiknas, 2010).

Berdasarkan kedua uraian tersebut, terdapat tiga learning outcome pokok yang harus dikuasi mahasiswa, yaitu: 1) kemampuan mengaplikasikan konsep-konsep baik keilmuan matematika maupun pendidikan matematika; 2) kemampuan memanfaatkan IPTEKS yang termasuk salah satu kecakapan hidup; dan 3) kemampuan melakukan penelitian sederhana. Proses yang harus dilaksanakan dalam mencapai learning outcome tersebut, salah satunya dengan mengenalkan dan memfasilitasi mahasiswa untuk melakukan penelitian dalam bidang pendidikan matematika.

Melakukan penelitian erat kaitannya dengan penguasaan konsep-konsep statistika. Hal ini dikarenakan penelitian merupakan serangkaian kegiatan yang meliputi pengumpulan data, pengolahan data, analisis data, interpretasi hasil, dan menarik kesimpulan dari hasil yang diperoleh (Ulpah, 2009). Pengolahan dan analisis data hanya bisa dilakukan jika mahasiswa menguasai konsep-konsep statistika. Oleh karena itu, mahasiswa dituntut untuk memahami dan menguasai konsep-konsep statistika sebagai syarat untuk mencapai learning outcome utama tersebut. Dengan kata lain, mahasiswa harus mampu mengembangkan kemampuan pemahaman konsep, supaya mampu mengaplikasikan konsep tersebut dalam kehidupan nyata.

Pemahaman konsep merupakan komponen penting dari pengetahuan yang diperlukan untuk mengatasi suatu masalah. Hal ini sejalan dengan pendapat Bransford, Brown dan Cocking (NCTM, 2000) yang menyatakan bahwa "Conceptual understanding is an important component of proficiency". Artinya pemahaman konseptual adalah komponen terpenting dari kecakapan. Adapun kecakapan yang diharapkan dalam pembelajaran matematika meliputi pemahaman konsep, pengetahuan prosedural, strategi kompetensi, penalaran dan komunikasi, serta menghargai kegunaan matematika. Selain itu, Bahr (2010) juga menyebutkan bahwa pemahaman konsep dan pengetahuan prosedural sama pentingnya dalam membangun kecakapan matematika, karena belajar dengan pemahaman juga membuat pembelajaran berikutnya menjadi lebih mudah. Namun, membelajarkan statistika tidak semudah yang dibayangkan. Terlalu banyaknya rumus yang digunakan membuat mahasiswa kurang memahami rumus dan penggunaannya, sehingga banyak mahasiswa yang tidak menyukai mata kuliah statistika (Susetyo, 2014). Akibatnya kemampuan pemahaman konsep mahasiswa tergolong rendah. 
Berdasarkan studi pendahuluan terhadap hasil ujian tengah semester 29 mahasiswa tahun akademik 2015/2016 di Universitas Muhammadiyah Sukabumi, hanya 41.38\% mahasiswa yang mencapai kompetensi yang telah ditetapkan, sedangkan 58.62\% mahasiswa belum mencapai kompetensi tersebut. Lebih lanjut, berdasarkan studi pendahuluan, beberapa kesulitan yang dihadapi mahasiswa dalam belajar statistika diantaranya: 1) belum mampu mengidentifikasi masalah dengan baik dan benar; 2) mahasiswa tidak memahami syarat awal atau asumsi yang harus dipenuhi dalam sebuah ilustrasi masalah; 3) mahasiswa tidak memahami penggunaan rumus; 4) kesalahan dalam memilih rumus yang sesuai dengan keadaan ilustrasi masalah; 5) kesalahan prosedural dan kesalahan penghitungan; dan 6) miskonsepsi.

Berdasarkan data tersebut, dapat disimpulkan bahwa memperbaiki kualitas belajar statistika sama halnya dengan meningkatkan kemampuan pemahaman konsep mahasiswa. Namun, pemahaman konsep akan tertanam dengan baik, jika proses pembelajaran yang dilakukan bermakna. Belajar bermakna menurut Ausubel (Dahar, 1996) yaitu suatu proses mengaitkan informasi baru pada konsep-konsep yang relevan yang terdapat dalam struktur kognitif seseorang. Belajar bermakna salah satunya dapat dilakukan dengan melibatkan pengalaman mahasiswa. Salah satu strategi pembelajaran yang melibatkan pengalaman mahasiswa adalah dengan mendesain bahan ajar berbasis Information and Communication Technology (ICT).

Pembelajaran berbasis ICT yaitu pembelajaran yang bertujuan untuk menghadirkan dunia di dalam kelas serta dapat disajikan kepada seluruh mahasiswa melalui peralatan ICT, seperti multimedia, pemanfaatan software-software pendukung pembelajaran, media pembelajaran hasil olahan komputer (poster, grafik, foto, gambar), pemanfaatan CD Interaktif, video Pembelajaran, multimedia presentasi, atau e-learning (Riyana, 2008). Pembelajaran berbasis ICT memiliki beberapa manfaat, diantaranya mampu mengilustrasikan konsep abstrak menjadi nyata, mempermudah perhitungan yang sulit dilakukan secara manual, mengefisienkan waktu, tenaga, dan biaya, serta dapat diulang-ulang sesuai kebutuhan.

Adapun tujuan penelitian ini adalah mengetahui validitas, kepraktisan, dan efektivitas bahan ajar statistika berbasis ICT yang dikembangkan untuk digunakan dalam proses pembelajaran khususnya dalam menumbuhkembangkan kemampuan pemahaman konsep mahasiswa. 


\section{METODE PENELITIAN}

Metode yang digunakan dalam penelitian ini adalah Research and Development taraf awal yang diaplikasikan dalam 2 tahap penelitian. Tahap pertama mencakup pengembangan bahan ajar. Beberapa hal yang dilakukan pada tahap ini diantaranya: a) menganalisis bahan ajar statistika yang akan dikembangkan melalui studi literatur, adapun materi yang terpilih adalah pengujian hipotesis; b) mengembangkan produk awal berupa desain web e-learning menggunakan software Chamilo, merancang bahan ajar statistika berbasis ICT pada materi pengujian hipotesis, membuat video tutorial beberapa uji hipotesis menggunakan bantuan aplikasi Ms. Excel, dan membuat rancangan tes dalam web e-learning; c) melakukan validasi bahan ajar berbasis ICT dan tampilan pada e-learning yang dikembangkan. Validasi ini dilakukan oleh tim validator yang terdiri dari 2 orang dosen pendidikan matematika (sebagai ahli materi) dan 1 orang dosen pendidikan teknologi informasi (sebagai ahli ICT) di Universitas Muhammadiyah Sukabumi; dan d) melakukan revisi tahap 1 berdasarkan rekomendasi dan komentar yang diberikan oleh tim validator.

Tahap kedua yaitu melakukan pengujian terbatas pada bahan ajar berbasis ICT yang sudah dikembangkan. Pengujian ini dilakukan terhadap 13 orang mahasiswa peserta mata kuliah Statistika pada Program Studi Pendidikan Matematika Universitas Muhammadiyah Sukabumi, yang dipilih secara acak sebagai pengguna produk dan melakukan revisi 2. Metode yang digunakan pada tahap kedua adalah metode eksperimen single one shot case study.

Pada tahap ini, pembelajaran menggunakan bahan ajar berbasis ICT diterapkan sebanyak 2 pertemuan, yaitu pada tanggal 6 Mei 2016 dan 13 Mei 2016. Pembelajaran ini dilaksanakan secara online dan tanpa bertatapan langsung dengan dosen pengampu mata kuliah. Mahasiswa secara mandiri diminta membuka web http://denzamy.web.id selanjutnya mendaftar sebagai peserta mata kuliah statistika dengan memasukkan username dan passwordnya masing-masing. Mahasiswa selanjutnya belajar secara mandiri menggunakan bahan ajar, bahan tayang, dan video tutorial yang bisa didownload dalam laman web tersebut. Setelah belajar mandiri, di akhir pertemuan pertama, mahasiswa diminta mengerjakan soal kuis dalam waktu 15 menit yang dilaksanakan secara online pula. Di akhir pertemuan kedua, mahasiswa diminta mengerjakan soal posttest dalam waktu 80 menit yang juga dikerjakan secara online. Masing-masing tes memiliki passing grade, yaitu 70 untuk soal kuis dan 65 
untuk soal posttest. Setelah itu, mahasiswa diminta mengisi lembar efektivitas kinerja bahan ajar sebelum dan sesudah penggunaan bahan ajar berbasis ICT. Hasil tes dan lembar efektivitas dalam uji coba tersebut selanjutnya dianalisis dan dibandingkan untuk melakukan revisi tahap 2 sebagai sarana perbaikan produk.

Instrumen yang digunakan dalam penelitian ini adalah lembar validasi, lembar efektivitas kinerja bahan ajar, dan tes kemampuan pemahaman konsep matematis. Data ini dianalisis menggunakan analisis deskriptif dan uji Wilcoxon Signed Ranks Test pada taraf $\alpha=5 \%$ menggunakan bantuan SPSS 19.

\section{HASIL DAN PEMBAHASAN}

Setelah melaksanakan kajian literatur mengenai ICT dan e-learning, tujuan pembelajaran statistika, capaian pembelajaran dalam mata kuliah statistika, serta materi yang dapat dikembangkan dalam bahan ajar berbasis ICT, terpilihlah materi pengujian hipotesis sebagai materi yang digunakan dalam penyusunan bahan ajar. Hal ini dikarenakan, materi pengujian hipotesis lebih mudah dipelajari dan diaplikasikan jika melibatkan banyak media berbasis ICT, baik berupa software pembelajaran maupun video tutorial.

Sebelum mengembangkan bahan ajar, terlebih dahulu dikembangkan web e-learning sebagai tempat, media, dan sumber belajar berbasis ICT. Web e-learning yang digunakan adalah web Chamilo. Hasil web e-learning yang dikembangkan dapat diakses pada laman http://denzamy.web.id. Selanjutnya untuk mengisi e-learning, dikembangkanlah bahan ajar berbasis ICT yang dilengkapi dengan video tutorial menggunakan Ms. Excel mengenai pengujian hipotesis. Bahan ajar yang dikembangkan terdiri dari 4 pokok bahasan, yaitu: a) pengujian normalitas data; b) pengujian homogenitas data; c) uji Z untuk satu dan dua sampel; dan d) uji T untuk satu dan dua sampel.

Setelah bahan ajar selesai disusun, bahan ajar selanjutnya divalidasi oleh 3 orang tim ahli, yang dalam hal ini 2 orang dosen Program Studi Pendidikan Matematika sebagai ahli materi, dan 1 orang dosen Program Studi Pendidikan Teknologi Informasi sebagai ahli ICT, pada Fakultas Keguruan dan Ilmu Pendidikan di Universitas Muhammadiyah Sukabumi.

Penilaian validitas bahan ajar dilihat dari aspek ahli materi ini mencakup 5 aspek, yaitu aspek kelayakan materi, kelayakan penggunaan bahasa, kelayakan penyajian bahan ajar, efektivitas bahan ajar terhadap proses belajar mengajar, dan kelayakan tampilan bahan ajar. Sedangkan validitas bahan ajar dilihat dari aspek ahli ICT mencakup 6 aspek, yaitu 
kemudahan berinteraksi dengan media, kejelasan video tutorial, tampilan bahan ajar, kejelasan pemilihan menu, dan kejelasan penggunaan bahasa, dan kesesuaian jenis tes yang dipilih. Keseluruhan validasi oleh tim ahli dinilai menggunakan skala 1-5, dengan kategori yaitu 1 (Tidak baik), 2 (Kurang baik), 3 (Cukup baik), 4 (Baik), dan 5 (Sangat baik). Untuk memperjelas penilaian, maka skala 1-5 selanjutnya diberikan kriteria sebagai berikut: kriteria 1 (jika kriteria yang terpenuhi kurang dari 20\%); kriteria 2 (jika 20-39\% kriteria telah terpenuhi); kriteria 3 (jika 40-59\% kriteria telah terpenuhi); kriteria 4 (jika 60-79\% kriteria telah terpenuhi); dan kriteria 5 (jika 80-100\% kriteria telah terpenuhi).

Berdasarkan hasil validasi ahli materi, aspek kelayakan materi memiliki rata-rata penilaian validator sebesar 4,71 dari skala 5 . Ini berarti lebih dari $80 \%$ materi yang digunakan dalam bahan ajar berbasis ICT sudah layak digunakan. Dengan kata lain, kesesuaian dan kelayakan materi yang digunakan dalam bahan ajar ini tergolong kategori sangat baik. Aspek kelayakan penggunaan bahasa memiliki rata-rata penilaian validator sebesar 4,63 dari skala 5 . Ini berarti lebih dari $80 \%$ bahasa yang digunakan dalam bahan ajar berbasis ICT sudah sesuai dengan kaidah Bahasa Indonesia yang baik dan benar. Dengan kata lain, kesesuaian dan kelayakan penggunaan bahasa yang digunakan dalam bahan ajar ini tergolong kategori sangat baik.

Aspek kelayakan penyajian bahan ajar memiliki rata-rata penilaian validator sebesar 4,75 dari skala 5. Ini berarti lebih dari $80 \%$ bahan ajar berbasis ICT disajikan dengan baik. Dengan kata lain, penyajian bahan ajar berbasis ICT ini tergolong kategori sangat baik. Aspek efektivitas bahan ajar terhadap proses belajar mengajar memiliki rata-rata penilaian validator sebesar 4,50 dari skala 5. Ini berarti lebih dari $80 \%$ bahan ajar berbasis ICT efektif digunakan dalam proses belajar mengajar. Dengan kata lain, efektivitas bahan ajar berbasis ICT terhadap proses belajar mengajar tergolong kategori sangat baik.

Aspek kelayakan tampilan bahan ajar memiliki rata-rata penilaian validator sebesar 5,00 dari skala 5. Ini berarti hampir 100\% bahan ajar berbasis ICT memiliki tampilan yang baik dan menarik. Dengan kata lain, tampilan bahan ajar berbasis ICT ini tergolong kategori sangat baik. Penilaian secara keseluruhan bahan ajar berbasis ICT memiliki rata-rata penilaian validator sebesar 4,72 dari skala 5. Ini berarti lebih dari $80 \%$ bahan ajar berbasis ICT sudah layak digunakan. Dengan kata lain, secara keseluruhan bahan ajar berbasis ICT ini tergolong kategori sangat baik, serta dapat langsung digunakan tanpa revisi. 
Berdasarkan hasil validasi ahli ICT, aspek kemudahan berinteraksi dengan media memiliki nilai 4 dari total skor 5 . Ini berarti lebih dari $80 \%$ bahan ajar berbasis ICT memiliki tingkat kemudahan yang tergolong kategori sangat baik, jika digunakan dalam pembelajaran. Aspek kejelasan video tutorial memiliki nilai 5 dari total skor 5. Ini berarti 100\% bahan ajar berbasis ICT menggunakan video tutorial yang jelas dan tergolong kategori sangat baik. Aspek tampilan bahan ajar memiliki nilai 5 dari total skor 5. Hal ini menunjukkan bahwa $100 \%$ bahan ajar berbasis ICT memiliki tampilan yang tergolong kategori sangat baik. Aspek kejelasan pemilihan menu memiliki nilai 4 dari total skor 5 . Hal ini menunjukkan bahwa lebih dari $80 \%$ bahan ajar berbasis ICT menggunakan menu yang sesuai dan tergolong kategori sangat baik.

Aspek kejelasan penggunaan bahasa memiliki nilai 5 dari total skor 5 . Hal ini menunjukkan bahwa 100\% bahan ajar berbasis ICT menggunakan Bahasa Indonesia yang baik dan benar serta tergolong kategori sangat baik. Aspek kesesuaian jenis tes yang dipilih memiliki nilai 4 dari total skor 5. Hal ini menunjukkan bahwa lebih dari $80 \%$ bahan ajar berbasis ICT menggunakan instrument tes yang sesuai dengan tujuan pembelajaran yang ingin dicapai. Penilaian secara keseluruhan ahli ICT memiliki nilai 4,50 dari total skor 5. Hal ini menunjukkan bahwa lebih dari $80 \%$ bahan ajar berbasis ICT sudah layak digunakan dan tergolong kategori sangat baik.

Meskipun sudah tergolong sangat baik, namun sebagai penyempurnaan tampilan bahan ajar, terdapat beberapa hal yang direvisi, diantaranya penambahan jumlah butir soal tes dan pengeditan tampilan. Hal ini dimaksudkan supaya mahasiswa lebih tertarik menggunakan bahan ajar dan tertantang untuk mengerjakan soal-soal yang bervariasi yang beragam.

Setelah selesai divalidasi oleh tim ahli, bahan ajar selanjutnya diuji coba terbatas pada skala kecil. Uji coba ini dilaksanakan selama 2 pertemuan pada 13 orang mahasiswa yang dipilih secara acak. Kegiatan ini meliputi pembelajaran secara online, pemberian post-test kemampuan pemahaman konsep secara online, dan pemberian lembar efektivitas kinerja bahan ajar sebelum dan sesudah pembelajaran berbasis ICT. Hasil uji coba terbatas ini dapat dilihat pada tabel 1 dan 2 sebagai berikut. Hasil ini dibandingkan dengan nilai yang diperoleh mahasiswa sebelum menggunakan bahan ajar berbasis ICT.

Tabel 1 Hasil Pretest dan Posttest Kemampuan Pemahaman Konsep

\begin{tabular}{cccc}
\hline No & Kode Mahasiswa & Pretest & Posttest \\
\hline 1 & M1 & 64.00 & 100.00
\end{tabular}




\begin{tabular}{cccc}
2 & M2 & 72.00 & 90.00 \\
3 & M3 & 63.00 & 95.00 \\
4 & M4 & 68.00 & 85.00 \\
5 & M5 & 64.00 & 100.00 \\
6 & M6 & 64.00 & 95.00 \\
7 & M7 & 56.50 & 100.00 \\
8 & M8 & 64.00 & 95.00 \\
9 & M9 & 51.50 & 95.00 \\
10 & M10 & 64.00 & 100.00 \\
11 & M11 & 64.00 & 95.00 \\
12 & M12 & 64.00 & 100.00 \\
13 & M13 & 64.00 & 100.00 \\
\hline
\end{tabular}

Tabel 2 Penilaian Efektivitas Kinerja Bahan Ajar 13 Mahasiswa

\begin{tabular}{ccc}
\hline $\begin{array}{c}\text { Pembelajaran dengan bahan } \\
\text { ajar ICT }\end{array}$ & Aspek yang diukur & $\begin{array}{c}\text { Pembelajaran tanpa bahan } \\
\text { ajar ICT }\end{array}$ \\
\hline $63.46 \%$ & $\begin{array}{c}\text { Kecepatan } \\
\text { Pemahaman }\end{array}$ & $48.08 \%$ \\
$67.31 \%$ & $\begin{array}{c}\text { Ketertarikan } \\
\text { Mahasiswa }\end{array}$ & $55.77 \%$ \\
$69.23 \%$ & $\begin{array}{l}\text { Kreativitas } \\
\text { Mahasiswa }\end{array}$ & $61.54 \%$ \\
$51.92 \%$ & $\begin{array}{c}\text { Hasil Belajar } \\
\text { Rata-rata }\end{array}$ & $76.92 \%$ \\
$62.98 \%$ & & $60.58 \%$ \\
\hline
\end{tabular}

Berdasarkan Tabel 1, pencapaian kemampuan pemahaman konsep matematis mahasiswa sebelum menggunakan bahan ajar, memiliki rata-rata skor 63.31 dari skor total 100, yaitu menunjukkan tingkat pemahaman sebesar 63,31\%, sedangkan pencapaian kemampuan pemahaman konsep matematis mahasiswa setelah menggunakan bahan ajar, memiliki rata-rata skor 96.15 dari skor total 100, yaitu menunjukkan tingkat pemahaman sebesar $96,15 \%$. Berdasarkan data tersebut, perbedaan rata-rata pencapaian kemampuan pemahaman konsep matematis sesudah dan sebelum penggunaan bahan ajar berbasis ICT terlihat cukup jauh berbeda, yaitu sebesar 32.85 point. Oleh karena itu, perlu dilakukan pengujian perbedaan rata-rata untuk melihat keberartian dari perbedaan efektivitas bahan ajar dalam aspek pencapaian kemampuan pemahaman konsep mahasiswa.

Sebelum melakukan pengujian perbedaan rata-rata mengenai pencapaian kemampuan pemahaman konsep matematis sebelum dan sesudah penggunaan bahan ajar berbasis ICT, terlebih dahulu dilakukan pengujian normalitas untuk menentukan jenis uji parametrik atau 
uji nonparametrik yang digunakan dalam pengujian hipotesis tersebut. Pengujian normalitas ini menggunakan uji Kolmogorov-smirnov dengan bantuan software SPSS 19 pada taraf signifikansi $\alpha=5 \%$. Hasil pengujian normalitas data dapat dilihat pada Tabel 3 berikut.

Tabel 3 Hasil Uji Normalitas Kemampuan Pemahaman Konsep Matematis

\begin{tabular}{cc}
\hline Jenis Tes & Signifikansi \\
\hline Pretest & 0.001 \\
Posttest & 0.018 \\
\hline
\end{tabular}

Berdasarkan Tabel 3, nilai signifikansi kedua data, baik data pretest maupun data posttest masing-masing adalah 0.001 dan 0.018 . Kedua nilai ini kurang dari $\alpha=5 \%$. Oleh karena itu, dapat disimpulkan bahwa kedua data baik pretest maupun posttest tidak berdistribusi normal. Dikarenakan kedua data tidak berdistribusi normal, maka pengujian perbedaan rata-rata kemampuan pemahaman konsep matematis dilakukan dengan menggunakan uji Wilcoxon Sign Rank Test dalam software SPSS 19 pada taraf signifikansi $\alpha=5 \%$.

Berdasarkan hasil pengujian perbedaan rata-rata menggunakan uji Wilcoxon Sign Rank Test, nilai signifikansi uji adalah 0.001. Nilai ini lebih kecil dari 5\%, sehingga dapat disimpulkan bahwa pencapaian kemampuan pemahaman konsep mahasiswa sesudah menggunakan bahan ajar statistika berbasis ICT lebih baik secara signifikan dari pada sebelum menggunakan bahan ajar berbasis ICT. Hal ini menunjukkan bahwa bahan ajar statistika berbasis ICT lebih efektif digunakan dalam pembelajaran sebagai upaya menumbuhkembangkan kemampuan pemahaman konsep mahasiswa.

Berdasarkan Tabel 2, penilaian efektivitas kinerja bahan ajar berbasis ICT dilihat dari aspek kecepatan pemahaman memiliki rata-rata $63.46 \%$. Hal ini lebih tinggi dibandingkan kecepatan pemahaman ketika pembelajaran dilakukan tanpa bahan ajar berbasis ICT, yaitu 48.08\%. Dilihat dari aspek ketertarikan mahasiswa dalam belajar dan mempelajari bahan ajar berbasis ICT memiliki rata-rata penilaian sebesar 67.13\%. Hal ini juga lebih tinggi dibandingkan dengan ketertarikan mahasiswa dalam belajar tanpa bahan ajar berbasis ICT, yaitu sebesar 55.77\%. Dilihat dari Aspek kreativitas mahasiswa dalam belajar statistika menggunakan bahan ajar berbasis ICT memiliki rata-rata penilaian sebesar $69.23 \%$. Keadaan ini juga lebih tinggi dibandingkan dengan kreativitas mahasiswa dalam belajar statistika tanpa menggunakan bahan ajar berbasis ICT, yaitu hanya sebesar 61.54\%. Berdasarkan 
ketiga aspek tersebut, kinerja bahan ajar berbasis ICT cukup efektif digunakan dalam pembelajaran statistika. Hasil perhitungan selengkapnya dapat dilihat pada lampiran.

Namun, dilihat dari aspek hasil belajar mahasiswa dalam mata kuliah statistika dengan menggunakan bahan ajar berbasis ICT hanya mencapai 51.92\%. Keadaan ini lebih rendah dibandingkan hasil belajar mahasiswa tanpa bahan ajar berbasis ICT, yang sudah mencapai $76.92 \%$. Berdasarkan komentar serta saran yang disampaikan mahasiswa dalam lembar efektivitas kinerja bahan ajar, keadaan ini terjadi dikarenakan mahasiswa lebih mengerti materi dan penyelesaian soal ketika bertatap muka dengan dosen di dalam kelas. Mahasiswa masih ingin dibimbing ketika mengalami kesulitan. Sedangkan ketika menggunakan bahan ajar berbasis ICT, mahasiswa lebih banyak belajar mandiri dengan sedikit bimbingan dosen.

Ditambah lagi dengan soal yang digunakan berbentuk online dan diacak secara otomatis oleh komputer, yang dirasa belum biasa digunakan dalam perkuliahan, mengakibatkan tingkat kecemasan mahasiswa menjadi lebih tinggi dibandingkan dengan tes tertulis biasa. Kecemasan lainnya yang dirasa meningkat adalah terputusnya koneksi internet yang mengakibatkan tes tertunda dan harus diulang. Hal ini pula lah yang membuat hasil belajar mahasiswa tidak lebih tinggi dari tes tulis biasa.

Meskipun demikian, rata-rata keseluruhan penilaian mengenai efektivitas kinerja bahan ajar berbasis ICT yaitu 62.98\%. Hal ini lebih tinggi dibandingkan dengan penilaian efektivitas kinerja tanpa bahan ajar berbasis ICT yaitu 60.58\%. Oleh karena itu, berdasarkan beberapa penilaian tersebut dapat ditarik kesimpulan bahwa bahan ajar berbasis ICT sudah memenuhi kriteria praktis dan efektif digunakan dalam pembelajaran statistika meskipun perlu beberapa revisi sebagai penyempurnaan produk.

Revisi yang dilakukan sebagai tindak lanjut dari hasil uji coba ini adalah menurunkan tingkat kesulitan soal-soal dalam test online dengan mengubahnya menjadi soal pilihan ganda. Hal ini dilakukan supaya mempermudah proses pemeriksaan jawaban, juga hasil tes dapat langsung dilihat oleh mahasiswa setelah tes selesai dilaksanakan. Revisi lainnya, yaitu menambahkan sejumlah soal dengan tipe yang sama namun rumus yang berbeda supaya mahasiswa lebih tertantang dan terbiasa mengerjakan soal yang bervariasi dan beragam dalam bentuk online. Selain itu, ditambahkan pula pengaturan passing grade (nilai ketuntasan minimal) dari masing-masing tes. Hal ini dimaksudkan supaya mahasiswa tidak asal menebak jawaban meskipun soal yang diberikan pilihan ganda. 


\section{KESIMPULAN}

Berdasarkan hasil validasi tim ahli, rata-rata skor penilaian bahan ajar statistika berbasis ICT adalah 4,50 dari total skor 5. Hal ini menunjukkan bahwa lebih dari $80 \%$ bahan ajar berbasis ICT yang dikembangkan sudah valid, layak digunakan, dan tergolong kategori sangat baik.

Berdasarkan hasil uji terbatas, dilihat dari pencapaian kemampuan pemahaman konsep mahasiswa sesudah menggunakan bahan ajar statistika berbasis ICT lebih baik secara signifikan dari pada sebelum menggunakan bahan ajar berbasis ICT. Selain itu, penilaian keseluruhan efektivitas kinerja bahan ajar berbasis ICT mencapai 62.98\%. Hal ini lebih tinggi dibandingkan dengan penilaian efektivitas kinerja pembelajaran tanpa bahan ajar berbasis ICT yang hanya mencapai $60.58 \%$. Data-data tersebut menunjukkan bahwa penggunaan bahan ajar berbasis ICT sudah memenuhi kriteria praktis dan efektif digunakan dalam pembelajaran statistika, sebagai upaya menumbuhkembangkan kemampuan pemahaman konsep matematis mahasiswa, meskipun perlu beberapa revisi sebagai penyempurnaan produk.

Revisi yang dilakukan sebagai tindak lanjut dari hasil uji coba skala kecil ini diantaranya: a) menurunkan tingkat kesulitan soal-soal dalam test online dengan mengubahnya menjadi soal pilihan ganda; b) menambahkan sejumlah soal sejenis dengan indikator yang digunakan namun lebih bervariasi; dan c) menambahkan pengaturan passing grade (nilai ketuntasan minimal) dari masing-masing tes.

\section{DAFTAR PUSTAKA}

Bahr, D. L. (2010). Elementary Mathematics is Anything but Elementary. USA: Wadsworth Cengage Learning.

Belmawa dan ALPTKI. (2013). Deskripsi Umum dan Learning Outcome 12 Prodi LPTK. Jakarta: Kemdikbud \& ALPTKI.

Dahar, R. W. (1996). Teori-teori Belajar. Jakarta: Erlangga.

Kemdiknas. (2010). Panduan Pengembangan bahan Ajar Berbasis TIK. Jakarta: Kemdiknas.

NCTM. (2000). Principles and Standards for School Mathematics. USA: The National Council of Theachers Mathematics Inc.

Riyana, C. (2008). Tekologi Informasi dan Komunikasi (ICT) dalam Pendidikan. 24 Desember 2015. https://klubgurusmi.files.wordpress.com.

Susetyo, B. (2014). Statistika untuk Analisis Data Penelitian Cetakan ke-3. Bandung: PT. Refika Aditama.

Ulpah, M. (2009). "Belajar Statistika: Mengapa dan Bagaimana?”. INSANIA Jurnal Pemikiran Alternatif Kependidikan Jurusan Tarbiyah STAIN Purwokerto. 14 (3), p.325-435. 